\title{
Skin Color and Maternal Near Miss: Exploring a Demographic and Health Survey in Brazil
}

\section{Cor de pele e Near Miss materno: explorando um inquérito demográfico de saúde no Brasil}

\author{
Karayna Gil Fernandes ${ }^{1,2}$ Maria Helena Sousa ${ }^{2}$ José Guilherme Cecatti ${ }^{1}$ \\ ${ }^{1}$ Department of Obstetrics and Gynecology, Faculdade de Ciências \\ Médicas, Universidade Estadual de Campinas, Campinas, \\ São Paulo, Brazil \\ 2 Faculdade de Medicina de Jundiaí, Jundiaí, São Paulo, Brazil

\begin{abstract}
Address for correspondence Jose Guilherme Cecatti, Department of Obstetrics and Gynecology, Universidade Estadual de Campinas, Rua Alexander Fleming, 101, 13083-891 Campinas, SP, Brazil
\end{abstract} \\ (e-mail: cecatti@unicamp.br).
}

Rev Bras Ginecol Obstet 2017;39:209-216.

\begin{abstract}
Keywords

- severe maternal morbidity

- maternal near miss

- pregnancy complications

- ethnicity

- maternal and child health
\end{abstract}

\section{Resumo}

Purpose In 2013, it was estimated that 289,000 maternal deaths occurred worldwide. The maternal mortality ratio has decreased in many countries in the past decades, due to early identification and treatment of obstetric complications, despite the dissimilarities observed in diverse locations and populations. Black women, for instance, have always been more susceptible to the occurrence of maternal mortality and severe morbidity. Therefore, the objective of this study is to assess skin color as a predictive factor for maternal near miss (MNM) in a sample of Brazilian women interviewed in the Brazilian National Demographic and Health Survey (DHS) of 2006. Method A secondary analysis of the DHS database, a population-based crosssectional nationally representative study was conducted. This database is of public domain. The risk of maternal complications according to ethnic group and the associated sociodemographic characteristics were evaluated. For the data analysis, the odds ratios and respective $95 \%$ confidence intervals were calculated.

Results In the sample interviewed, 59\% of women were black or brown (mixed-race). Approximately $23 \%$ of women had some complication, and $2 \%$ of these women had at least one MNM pragmatic criterion. The MNM rate was 31 per 1,000 live births, and its occurrence was not statistically different among the ethnic groups. The only factors identified that were considered to be associated with the occurrence of MNM were maternal age above 40 and women not currently attending school, but only among white women.

Conclusion The 2006 DHS results did not show a higher occurrence of maternal complications, and specifically of MNM associated with black/brown skin color.

Objetivo Estima-se que em 2013 tenham ocorrido 289.000 mortes maternas no mundo. Observou-se uma redução na razão de mortalidade materna em muitos países nas últimas décadas, e isso se deveu à identificação e tratamento precoce das complicações obstétricas, embora de forma não similar entre os diversos locais e received

January 16, 2017

accepted

March 14, 2017

published online

May 22, 2017
DOI https://doi.org/

10.1055/s-0037-1603498. ISSN 0100-7203.
Copyright $\odot 2017$ by Thieme Revinter

Publicações Ltda, Rio de Janeiro, Brazil
License terms

(ㄷ) (i) $\ominus$ (5) 


\author{
Palavras-chave \\ - morbidade materna \\ grave \\ - near miss materno \\ - complicações da \\ gestação \\ - etnia \\ - saúde materna e \\ infantil
}

\begin{abstract}
populações. As mulheres negras, por exemplo, sempre estiveram mais sujeitas à ocorrência de mortalidade materna e de morbidade grave. Então, o objetivo desse estudo foi avaliar a cor da pele como fator preditor de Near Miss materno (NMM) em uma amostra de mulheres brasileiras entrevistadas na Pesquisa Nacional de Demografia e Saúde (PNDS) de 2006.

Método Análise secundária do banco de dados da PNDS, um estudo transversal de base populacional e com representatividade nacional, sendo este banco de dados de domínio público. Avaliou-se o risco de complicações maternas por grupo de cor da pele e as características sociodemográficas associadas. Para a análise dos dados, as razões de possibilidades e os respectivos intervalos de confiança de $95 \%$ foram calculados.

Resultados $\mathrm{Na}$ amostra entrevistada, $59 \%$ das mulheres eram negras ou pardas. Aproximadamente $23 \%$ das mulheres apresentaram alguma complicação, e $2 \%$ delas, pelo menos um critério pragmático de NMM. A taxa de NMM foi de 31 por 1.000 nascidos vivos, e sua ocorrência não foi estatisticamente diferente entre os grupos de cor da pele. Os únicos fatores identificados como associados à ocorrência de NMM foram a idade materna acima de 40 anos e não estar atualmente estudando, mas apenas entre as mulheres brancas.

Conclusão Os resultados da PNDS 2006 não mostraram uma maior ocorrência de complicações maternas e especificamente de NMM associadas à cor da pele negra/ parda.
\end{abstract}

\section{Introduction}

In 2013 , it was estimated that 289,000 maternal deaths occurred worldwide. A total of 2,300 of those deaths occurred in high-income countries. The figure for middleincome and low-income countries was 286,000 deaths, and 2,100 of those maternal deaths occured in Brazil in that year. ${ }^{1}$ One of the United Nations Millennium Development Goals was to reduce the maternal mortality ratio by 75\% from 1990 until 2015 in the world. However, from 1990 until 2013, the ratio decreased only $45 \%$. The highest progress occurred between the years 2000 and 2013, when maternal mortality declined $3.5 \%$ per year. ${ }^{1}$

The reduction in the maternal mortality ratio observed in some countries is due to the early identification and treatment of obstetric complications. ${ }^{2}$ In order to make this happen, information that is systematically collected on the occurrence of morbidities should be considered, especially life-threatening conditions termed maternal near miss (MNM), among more vulnerable women who comprise a high-risk group. ${ }^{3}$

It is well-known that certain ethnic groups are more prone to develop certain health conditions, and this is inter-related with chronic medical conditions and socioeconomic status. ${ }^{4}$ According to a study conducted in the United Kingdom, women of African descent, or who are Caribbean and Pakistani tend to have more severe maternal morbidity than white women. This may be related to a preexisting maternal factor, or related factors during pregnancy, labor and childbirth. ${ }^{5,6}$ In Brazil, it has already been identified that black women also have a higher maternal mortality rate. ${ }^{7}$
Although maternal skin color is most commonly considered, there are indications that paternal skin color may also be associated with the occurrence of unfavorable conditions during pregnancy. An American study demonstrated that preeclampsia was associated not only with maternal skin color, but also with paternal skin color. ${ }^{8}$ The prevalence of preeclampsia, eclampsia, abruptio placentae, placenta previa and postpartum hemorrhage did not differ in black and white women, but the fatality rate of these conditions was 2- to 3-fold higher in black women. ${ }^{9}$

The aim of this study was to assess maternal skin color as a predictive factor for MNM events in a sample of Brazilian women interviewed in the Brazilian National Demographic and Health Survey (DHS) of Children and Women of 2006, as a contribution for increasing the knowledge on the role of ethnic differentials in determing severe maternal outcomes in Brazil.

\section{Methods}

This study is a secondary analysis of the database of the DHS. Ethical approval for this national survey was obtained before the beginning of the data collection. The respective database is currently of public domain, and can be used without restrictions. ${ }^{10}$ The study was performed according to the Declaration of Helsinki, which was reviewed in 2008. The DHS used a questionnaire validated to recognize maternal complications and maternal interventions that were associated with severe maternal morbidity, according to the women's self-report. This questionnaire was validated and based on the results of a systematic review. ${ }^{11,12}$ 
The DHS was a household survey performed by probabilistic sampling that included a subsample of the 2005 National Survey of Households conducted in the five regions of Brazil. Details on the study methods were published previously. ${ }^{10,11}$ Initially, 14,617 households were selected for the 2006 DHS. Women in reproductive age (15 to 49 years) living in a particular household, irrespective of marital status, as well as these women's children aged 5 years or younger at the time of the interview (born after January 2001) were included in this study. Thus, 13,056 households that had at least one eligible woman were included in the study. ${ }^{10}$

All characteristics reported by the interviewees who had given birth in the last five years, including their sociodemographic data, history of complications and interventions, were analyzed according to the region of the country where these women lived. ${ }^{10}$

Maternal near miss was assessed by a pragmatic definition of "near death," and was considered to have existed when the woman reported: eclampsia, hysterectomy, blood transfusion and/or admission to an intensive care unit (ICU), which had occurred at childbirth during the reference period. ${ }^{13}$ This definition was based on the results of a secondary analysis of data from the World Health Organization (WHO). In that study, data was obtained from $\sim 100,000$ deliveries in Latin America, and the same characteristics that defined the term maternal near miss, in addition to any cardiac or renal complications, were identified. ${ }^{13}$ The components of this definition were confirmed by a validation study that correlated data from medical charts and information obtained from patient reports on the events that had occurred (hysterectomy, blood transfusion, ICU admission and eclampsia), and showed a good correlation between both. ${ }^{11}$ Therefore, the reported complications that had not been included in the definition of MNM were identified as potentially lifethreatening maternal conditions.

For the current analysis, which focused on ethnic determinants, we operationally defined three ethnic or skin color groups, formed by white, black, and brown (mixed-race) women; there were also other categories, and they were all self-reported by the women. The response rates and number of live births per ethnic group were evaluated. The ethnic distribution of women with at least one live child was estimated for each region of the country using weighted data. The proportion of pregnancies with self-reported complications/interventions related to each ethnic or skin color group was assessed. Crude and adjusted rates of self-reported MNM for each ethnic group were then estimated. The risks of maternal complications were then evaluated for each ethnic or skin color group based on some available sociodemographic characteristics. For the statistical data analysis, the diferences between groups for qualitative variables were evaluated by the chi-squared $\left(\chi^{2}\right)$ test. For the estimates of the indicators, the values of the respective $95 \%$ confidence intervals ( $95 \% \mathrm{CIs}$ ) were also provided. To analyze the factors associated with the risk of maternal morbidity in the different ethnic groups, the odds ratios (ORs) and their respective $95 \%$ CIs were calculated.

For the statistical analysis, characteristics (of regional stratification, primary sampling unit, and sampling weights) of the complex DHS sampling plan were taken into account. For the tests used, $p$-values lower than 0.05 were considered significant. The analyses were performed using the Statistical Package for the Social Sciences (SPSS, SPSS Inc., Chicago, IL, US) software, version 17.0, and the Stata (StataCorp, College Station, TX, US) software, version 7.0.

\section{Results}

The 2006 DHS selected 17,456 eligible women in the five regions of Brazil, interviewing 15,575 women. Of these, 5,025 women had delivered at least one live born child since January 2001, constituting the population to be aevaluated in our study. The total number of pregnancies in the last five years was 6,833, and live births numbered 5,056 during this same period. Thus, it was possible to estimate the expanded sample of $19,987,263$ pregnancies in the entire national territory ( $\mathbf{- T a b l e ~} \mathbf{1})$.

Table 1 Response rates and live births by skin color group. DHS, Brazil, 2006

\begin{tabular}{|c|c|c|c|c|c|c|c|c|}
\hline \multirow[t]{3}{*}{ Characteristics } & \multicolumn{6}{|c|}{ Ethnic Group } & \multirow{3}{*}{$\begin{array}{l}\text { Total with } \\
\text { skin color }\end{array}$} & \multirow[t]{3}{*}{ Total } \\
\hline & \multicolumn{2}{|c|}{$\begin{array}{l}\text { Black + mixed- } \\
\text { race }\end{array}$} & \multicolumn{2}{|l|}{ White } & \multicolumn{2}{|l|}{ Others } & & \\
\hline & $\mathbf{n}$ & $\%$ & $\mathbf{n}$ & $\%$ & $\mathbf{n}$ & $\%$ & & \\
\hline Women eligible & - & - & - & - & - & - & - & 17,456 \\
\hline Women interviewed & 8,638 & 56.0 & 5,987 & 38.8 & 807 & 5.2 & 15,432 & $15,575^{\mathrm{a}}$ \\
\hline Response rate among women (\%) & - & - & - & - & - & - & - & 89.2 \\
\hline Women with at least one LB & 2,924 & 58.9 & 1,786 & 36.0 & 256 & 5.1 & 4,966 & $5,025^{b}$ \\
\hline LBs & 3,019 & 60.4 & 1,716 & 34.4 & 260 & 5.2 & 4,995 & $5,056^{c}$ \\
\hline Pregnancies & 4,080 & 60.4 & 2,308 & 34.2 & 365 & 5.4 & 6,753 & $6,833^{d}$ \\
\hline Pregnancies (expanded sample) & $11,907.135$ & 60.2 & $6,717.818$ & 34.0 & $1,149.026$ & 5.8 & $19,773.979$ & $19,987.263^{\mathrm{e}}$ \\
\hline
\end{tabular}

Abbreviations: DHS, Demographic and Health Survey, LB, live birth.

Notes: ${ }^{\mathrm{a}}$ Missing information for ethnic group: $143{ }^{\mathrm{b}}$ missing information for ethnic group: $59 ;{ }^{\mathrm{c}}$ missing information for ethnic group: $61 ;{ }^{\mathrm{d}}$ missing information for ethnic group: 80 ; ${ }^{\mathrm{e}}$ missing information for ethnic group: 213,284 . 
212 Skin Color and Maternal Near Miss Fernandes et al.

Table 2 Ethnic distribution by region for women with at least one live birth. DHS, Brazil, 2006

\begin{tabular}{|l|l|l|l|l|l|l|}
\hline \multirow{2}{*}{ Skin color } & \multicolumn{6}{|l|}{ Region } \\
\cline { 2 - 7 } & Northern & Northeastern & Southeastern & Southern & Midwestern & Total \\
\hline \multirow{3}{*}{ Black + mixed-race } & 786 & 671 & 545 & 305 & 617 & 2,924 \\
\cline { 2 - 7 } & {$[79.8]$} & {$[72.4]$} & {$[54.9]$} & {$[29.0]$} & {$[60.0]$} & {$[59.0]$} \\
\hline \multirow{3}{*}{ White } & 172 & 229 & 380 & 665 & 340 & 1,786 \\
\cline { 2 - 7 } & {$[15.9]$} & {$[23.3]$} & {$[37.6]$} & {$[66.9]$} & {$[34.2]$} & {$[35.3]$} \\
\hline \multirow{3}{*}{ Others } & 43 & 44 & 56 & 37 & 76 & 256 \\
\cline { 2 - 7 } & {$[4.4]$} & {$[4.3]$} & {$[7.4]$} & {$[4.1]$} & {$[5.9]$} & {$[5.7]$} \\
\hline Total & 1,001 & 944 & 981 & 1,007 & 1,033 & 4,966 \\
\hline
\end{tabular}

Abbreviation: DHS, Demographic and Health Survey.

Notes: [ ] \% weighted data; $p<0.001$ (design-based).

The majority of black and brown (mixed-race) women lived in the Northern, Northeastern and Midwestern Regions, and represented the majority of the women in reproductive age. In contrast, white women from the same group accounted for $35 \%$ of the sample, and lived most frequently in the Southern Region of the country (-Table 2 ).

-Table 3 shows the proportions of pregnancies with selfreported complications and interventions per ethnic group. Approximately $23 \%$ of the women reported having at least one maternal complication or procedure related to the complication (eclampsia, hemorrhage, infection, hysterectomy, ICU admission, blood transfusion, inter-hospital transfer, mechanical ventilation, hospital stay lasting more than a week in the postpartum period), while only $2 \%$ of them reported having experienced some conditions characterized as a MNM events (eclampsia, hysterectomy, ICU admission or blood transfusion). White women had a higher rate of eclampsia ( $8 \%$ ) and infection (1.2\%). On the other hand, black and mixed-race women had a higher proportion of hemorrhage (19.2\%), prolonged hospital stay lasting more than a week in the postpartum period (4.3\%), and ICU admission (0.7\%) than white women and the other groups. However, these differences were not significant for any of the complications evaluated.

- Table 4 shows the rate of self-reported MNM events, according to the pragmatic definition that was used in our study, for the different ethnic groups considered. The global MNM ratio was 31 per 1,000 live births, meaning that $\sim 3$ out of 100 women delivering live newborns would have some type of maternal complication during delivery or the postpartum period. Although this ratio is higher in black and brown women, as well as in other ethnic groups, such ratios were not significantly different among groups.

When the sociodemographic characteristics of the women were associated with the risk of maternal complications according to the ethnic group, it was observed that a higher risk existed in white women and other ethnic groups, in the age range of 40 to 49 years (OR: 6.48 [1.2832.90]). The estimated risk is still lower for white women and women of other ethnicities who are currently attending school (OR: 0.21 [0.04-0.97]). No associations were found between the occurrence of MNM and the amount of years of education, marital status, place of residence, region, employment during the last 12 months, number of live births, and family income (-Table 5) for any of the ethnic groups considered.

\section{Discussion}

The current analysis was conducted in an exploratory manner to confirm whether skin color, especially black, plays a role in determining a higher risk of severe maternal complications among Brazilian women. There is a relative scarcity of scientifically generated information about this association, especially in Brazil. In summary, the current study was based on interviews of women in the 2006 DHS, and showed a predominance of black and mixed-race ethnic groups, and other ethnicities (including the Brazilian Indians), in lowincome Brazilian regions, notably the Northern and Northeastern Regions. This had already been expected. While $23 \%$ of women reported having some type of severe pregnancy-related complication, the occurrence of an MNM event as defined pragmatically was of 31 per 1,000 live births, or $\sim 3 \%$. This rate was higher than those of other population-based assessments of MNM events. ${ }^{14}$ Nevertheless, the occurrence of each of the diverse severe conditions, associations or at least one association studied, did not show a significantly different distribution among the distinct skin color groups considered, contrary to what had been imagined. This fact could possibly be explained by the high degree of miscegenation found in Brazil.

An ethnic predominance of black and brown women in the Northern and Northeastern Regions of Brazil could be observed in the DHS study. In fact, according to the 2010 Brazilian National Census data, $43.1 \%$ of the Brazilian population self-reported as being pardo (brown/mixed race in Portuguese), and the majority of these individuals were in the Northern Region (66.9\%), while only $16.5 \%$ were found in the Southern Region. Those who self-reported as being black totalized $7.6 \%$, with the highest percentage in the Northeastern Region (9.5\%) and the lowest in the Southern Region (4.1\%). ${ }^{15}$ 
Table 3 Proportion of pregnancies with complications and related interventions by skin color group. DHS, Brazil, 2006

\begin{tabular}{|c|c|c|c|c|c|}
\hline \multirow[t]{2}{*}{ Complications and related interventions } & \multicolumn{3}{|l|}{ Skin color group } & \multirow[t]{2}{*}{$p^{*}$} & \multirow[t]{2}{*}{ Total } \\
\hline & Black + mixed-race & White & Others & & \\
\hline \multirow{2}{*}{ Eclampsia (a) } & 37 & 17 & 4 & 0.472 & 58 \\
\hline & [0.5] & {$[0.8]$} & {$[0.2]$} & & {$[0.6]$} \\
\hline \multirow[t]{2}{*}{ Hemorrhage (b) } & 720 & 383 & 57 & 0.446 & 1160 \\
\hline & {$[19.2]$} & {$[17.5]$} & {$[15.2]$} & & {$[18.4]$} \\
\hline \multirow[t]{2}{*}{ Infection (c) } & 55 & 26 & 2 & 0.460 & 83 \\
\hline & [0.9] & {$[1.2]$} & {$[0.3]$} & & {$[1.0]$} \\
\hline \multirow[t]{2}{*}{ Hysterectomy (d) } & 8 & 2 & 1 & 0.307 & 11 \\
\hline & [0.1] & {$[0.3]$} & {$[0.7]$} & & {$[0.2]$} \\
\hline \multirow[t]{2}{*}{ ICU admission (e) } & 29 & 11 & 2 & 0.100 & 42 \\
\hline & [0.7] & {$[0.3]$} & {$[0.1]$} & & {$[0.5]$} \\
\hline \multirow[t]{2}{*}{ Blood transfusion ( $f$ ) } & 39 & 18 & 5 & 0.867 & 62 \\
\hline & [0.9] & {$[0.7]$} & {$[1.1]$} & & {$[0.8]$} \\
\hline \multirow[t]{2}{*}{ Inter-hospital transfer (g) } & 91 & 39 & 11 & 0.122 & 141 \\
\hline & [2.4] & {$[1.6]$} & {$[5.5]$} & & {$[2.4]$} \\
\hline \multirow[t]{2}{*}{ Mechanical ventilation (h) } & 66 & 32 & 8 & 0.173 & 106 \\
\hline & [1.9] & {$[1.1]$} & {$[3.9]$} & & {$[1.7]$} \\
\hline \multirow[t]{2}{*}{ Postpartum stay $>1$ week (h) } & 159 & 73 & 7 & 0.805 & 239 \\
\hline & {$[4.3]$} & {$[3.6]$} & {$[4.1]$} & & {$[4.0]$} \\
\hline \multirow{2}{*}{$\begin{array}{l}\text { Any of the previous } \\
\text { complications/ interventions (i) }\end{array}$} & 883 & 456 & 66 & 0.409 & 1405 \\
\hline & {$[24.0]$} & {$[21.1]$} & {$[22.0]$} & & {$[22.9]$} \\
\hline \multirow{2}{*}{$\begin{array}{l}\text { MNM (eclampsia, hysterectomy, } \\
\text { ICU admission, blood transfusion) (j) }\end{array}$} & 101 & 42 & 12 & & 155 \\
\hline & {$[2.0]$} & {$[2.0]$} & {$[2.3]$} & 0.963 & {$[2.0]$} \\
\hline $\begin{array}{l}\text { Pregnancies in the } 5 \text { years before } \\
\text { the interview (expanded sample) }\end{array}$ & $11,907.135$ & $6,717.818$ & $1,149.026$ & & $19,773.979$ \\
\hline Pregnancies (n) • & 4,080 & 2,308 & 365 & & 6,753 \\
\hline
\end{tabular}

Abbreviations: DHS, Demographic and Health Survey; ICU, intensive care unit; MNM, maternal near miss.

Notes: * Design-based; [ ] \% weighted data; • Missing information for ethnic group: 80 pregnancies. Missing information for more: (a) 102 pregnancies; (b) 73; (c) 113; (d) 410; (e) 81; (f) 92; (g) 76; (h) 83; (i) 287; (j) 435.

Women randomly eligible for the DHS study could be evaluated in diverse living, intellectual, social, economic and cultural conditions, including ethnic differences. It is wellknown that all of these factors are also associated with the quality of the healthcare provided to women during pregnancy, childbirth and the postpartum period, which seems to be more closely associated with socioeconomic conditions. Another large national prospective study also failed to find any association between ethnic characteristics and the occurrence of MNM, although it identified that white women with a higher level of education had a more frequent and better access to prenatal and maternity healthcare. ${ }^{16}$

In the evaluation of the indicators, the MNM ratios did not vary significantly among groups, even though the women classified as belonging to other ethnic groups showed a higher ratio. This result may be due to the inclusion of Brazilian Indian women in this category. Although fewer in number, Indian women have very limited access to high- quality health services during pregnancy. Unfortunately, the number of native Indian women interviewed did not allow a particularized analysis of the occurrence of maternal morbidity in this group. Assessments performed in other contexts have already shown that Native American women and those native to Alaska have a higher risk of preeclampsia than white women, and this effect is also modulated by body mass index (BMI). ${ }^{17}$

In general, the results of the current study diverge from other studies in the literature that were related to the subject. In the United Kingdom, a case-control study demonstrated that black African women had twice the chance of having an MNM event in comparison to white Europeans. ${ }^{6}$ The nationwide incidence of severe acute maternal morbidity was of 7.1 per 1,000 live births in the Netherlands, and was subject to wide variations according to skin color, with women from Sub-Saharan Africa exhibiting a risk that is 3.5-fold higher than for Turkish and Moroccan women. ${ }^{18}$ The 
214 Skin Color and Maternal Near Miss Fernandes et al.

Table 4 Skin color specific crude rates of self-reported MNM. DHS, Brazil, 2006

\begin{tabular}{|c|c|c|c|c|}
\hline \multirow[t]{2}{*}{ Indicator of MNM } & \multirow{2}{*}{$\begin{array}{l}\text { MNMR } \\
\text { (per } 1,000 \text { LBs) }\end{array}$} & \multicolumn{3}{|c|}{ Skin color specific MNMR } \\
\hline & & $\begin{array}{l}\text { Black + } \\
\text { mixed-race }\end{array}$ & White & Others \\
\hline \multirow[t]{2}{*}{ Eclampsia } & 11.6 & 12.3 & 9.9 & 15.4 \\
\hline & {$[8.8-15.0]$} & [8.6-16.9] & {$[5.8-15.8]$} & {$[4.2-38.9]$} \\
\hline \multirow[t]{2}{*}{ Hysterectomy } & 2.2 & 2.6 & 1.2 & 3.8 \\
\hline & {$[1.1-3.9]$} & {$[1.1-5.2]$} & {$[0.1-4.2]$} & {$[<0.1-21.2]$} \\
\hline \multirow[t]{2}{*}{ ICU admission } & 8.4 & 9.6 & 6.4 & 7.7 \\
\hline & {$[6.1-11.3]$} & {$[6.4-13.8]$} & {$[3.2-11.4]$} & {$[0.9-27.5]$} \\
\hline \multirow[t]{2}{*}{ Blood transfusion } & 12.4 & 12.9 & 10.5 & 19.2 \\
\hline & [9.5-15.9] & {$[9.2-17.6]$} & {$[6.2-16.5]$} & {$[6.3-44.3]$} \\
\hline \multirow[t]{2}{*}{ Any of the 4 previous indicators } & 31.0 & 33.5 & 24.5 & 46.2 \\
\hline & {$[26.4-36.2]$} & {$[27.3-40.5]$} & [17.7-32.9] & [24.1-79.2] \\
\hline Number of LBs & 4,995 & 3,019 & 1,716 & 260 \\
\hline
\end{tabular}

Abbreviations: DHS, Demographic and Health Survey; ICU, intensive care unit; LBs, live births; MNM, maternal near miss; MNMR, maternal near miss rate.

Note: [ ] 95\% Confidence interval for MNMR (exact binomial).

Table 5 Adjusted estimated risk of maternal complications by skin color group according to sociodemographic characteristics. DHS, Brazil, 2006

\begin{tabular}{|c|c|c|c|c|c|c|}
\hline \multirow[t]{3}{*}{ Patient characteristics } & \multicolumn{3}{|c|}{$\begin{array}{l}\text { Skin color group: Black }+ \text { mixed } \\
\text { race }\end{array}$} & \multicolumn{3}{|c|}{ Skin color group: White + Others } \\
\hline & \multicolumn{3}{|c|}{ Complication } & \multicolumn{3}{|c|}{ Complication } \\
\hline & Yes & No & OR (95\%Cl) \# & Yes & No & OR (95\%Cl) \# \\
\hline \multicolumn{7}{|l|}{ Schooling, years } \\
\hline No education/ primary education only & 58 & 1,735 & $1.83[0.70-4.74]$ & 27 & 1,040 & $1.00[0.45-2.24]$ \\
\hline High school & 17 & 1,071 & 1.00 (ref.) & 15 & 916 & 1.00 (ref.) \\
\hline \multicolumn{7}{|l|}{ Currently attending school } \\
\hline No & 65 & 2,432 & 1.00 (ref.) & 38 & 1,742 & 1.00 (ref.) \\
\hline Yes & 10 & 375 & $1.61[0.64-4.03]$ & 4 & 214 & $0.21[0.04-0.97]$ \\
\hline \multicolumn{7}{|l|}{ Marital status } \\
\hline Without partner & 14 & 511 & 1.00 (ref.) & 8 & 297 & 1.00 (ref.) \\
\hline With partner & 61 & 2,294 & $0.78[0.28-2.16]$ & 34 & 1,658 & $2.86[0.62-13.18]$ \\
\hline \multicolumn{7}{|l|}{ Maternal Age } \\
\hline Up to 29 years & 39 & 1,794 & 1.00 (ref.) & 21 & 1,157 & 1.00 (ref.) \\
\hline $30-39$ years & 28 & 860 & $1.95[0.80-4.72]$ & 16 & 652 & $2.17[0.46-10.24]$ \\
\hline 40-49years & 8 & 154 & $0.64[0.18-2.28]$ & 5 & 147 & $6.48[1.28-32.90]$ \\
\hline \multicolumn{7}{|l|}{ Location of residence } \\
\hline Rural & 21 & 929 & 1.00 (ref.) & 16 & 634 & 1.00 (ref.) \\
\hline Urban & 54 & 1,879 & $1.71[0.70-4.18]$ & 26 & 1,322 & 0.62 [0.20-1.99] \\
\hline \multicolumn{7}{|l|}{ Region } \\
\hline $\mathrm{N}, \mathrm{NE}, \mathrm{MW}$ & 54 & 1,990 & $1.07[0.39-2.92]$ & 21 & 860 & $0.51[0.17-1.55]$ \\
\hline S, SE & 21 & 818 & 1.00 (ref.) & 21 & 1,096 & 1.00 (ref.) \\
\hline \multicolumn{7}{|l|}{ Working in the last 12 months } \\
\hline Yes & 48 & 1,579 & $1.32[0.57-3.05]$ & 27 & 1,195 & $0.95[0.20-4.64]$ \\
\hline
\end{tabular}


Table 5 (Continued)

\begin{tabular}{|c|c|c|c|c|c|c|}
\hline \multirow[t]{3}{*}{ Patient characteristics } & \multicolumn{3}{|c|}{$\begin{array}{l}\text { Skin color group: Black + mixed } \\
\text { race }\end{array}$} & \multicolumn{3}{|c|}{ Skin color group: White + Others } \\
\hline & \multicolumn{3}{|c|}{ Complication } & \multicolumn{3}{|c|}{ Complication } \\
\hline & Yes & No & OR $(95 \% \mathrm{Cl}) \#$ & Yes & No & OR $(95 \% \mathrm{Cl}) \#$ \\
\hline No & 27 & 1,227 & 1.00 (ref.) & 15 & 760 & 1.00 (ref.) \\
\hline \multicolumn{7}{|l|}{ Number of live births } \\
\hline$\geq 2$ & 51 & 1,743 & $1.09[0.49-2.44]$ & 27 & 1,126 & $0.50[0.17-1.45]$ \\
\hline$<2$ & 24 & 1,065 & 1.00 (ref.) & 15 & 830 & 1.00 (ref.) \\
\hline \multicolumn{7}{|l|}{ Income } \\
\hline$\leq \mathrm{R} \$ 400$ & 33 & 1,153 & $2.69[0.73-9.89]$ & 17 & 541 & $2.35[0.57-9.64]$ \\
\hline $\mathrm{R} \$ 401-\mathrm{R} \$ 800$ & 20 & 680 & $3.40[0.84-13.82]$ & 8 & 442 & $0.29[0.08-1.05]$ \\
\hline$>R \$ 800$ & 10 & 661 & 1.00 (ref.) & 12 & 693 & 1.00 (ref.) \\
\hline Total women & 75 & 2,808 & & 42 & 1,956 & \\
\hline
\end{tabular}

Abbreviations: 95\%Cl, 95\% confidence interval; DHS, Demographic and Health Survey; MW. Midwestern Region; N, Northern Region; NE, Northeastern Region; S, Southern Region; SE, Southeastern Region; R\$, real, the Brazilian currency; Ref., reference.

Notes: \# Adjusted for the sampling design: weight, stratum and cluster (PSU, primary sampling unit), and for all aforementioned sociodemographic characteristics; $n=2,551$ for the first, and $n=1,712$ for the last ethnic group; values in bold mean they are statistically significant.

subject is more widely explored in the North-American continent, where multiple studies show similar results of a higher risk of maternal death and severe maternal morbidity among black women in comparison to white women. This demonstrates that the quality of the healthcare in locations where black women give birth has a limited role. ${ }^{19-21}$

The current study may have some limitations that should be considered. One limitation is that the woman self-defines her skin color, as well as the occurrence of pregnancy-related complications that characterize severe maternal morbidity and near miss events. Although self-reporting on maternal morbidity is used with some frequency, it is known that the degree of precision of such information is limited for some conditions such as hypertension and infection. The results were based on data collected in 2006, although they derived from a well-conducted Demographic and Health Survey (the 2006 DHS). Therefore, the survey did not contain all the data that could be useful to better investigate the determinants and consequences of possible ethnic differentials during childbirth care. Future population-based studies with an adequate number of women from all minority ethnic groups or underprivileged women, including the migrant population, may be important to generate a scientifically based understanding of such a vital and current topic.

Even though the current analysis, based on the 2006 DHS, did not demonstrate a significant increase in the occurrence of severe maternal morbidity and near miss events among black and brown (mixed-race) women in comparison to white women in Brazil, it indicated some sociodemographic characteristics that were most frequently associated with maternity among underprivileged women, including ethnic minorities. Only socioeconomic equality between populations, as well as improvements in the quality of the healthcare provided to all women, can minimize the differences in maternal and perinatal outcomes between different ethnic groups.

\section{Conflicts of Interest}

The authors do not have any conflicts of interest to disclose regarding the current study.

\section{References}

1 World Health Organization [Internet]. Trends in maternal mortality: 1990 to 2013: estimates by WHO, UNICEF, UNFPA, The World Bank and the United Nations Population Division. Geneva: WHO; 2014 [cited 2015 Sep 8]. Available from: http://www.who. int/reproductivehealth/publications/monitoring/maternal-mortality-2013/en/

2 Paxton A, Maine D, Freedman L, Fry D, Lobis S. The evidence for emergency obstetric care. Int J Gynaecol Obstet 2005; 88(02):181-193

3 Say L, Souza JP, Pattinson RC; WHO working group on Maternal Mortality and Morbidity classifications. Maternal near misstowards a standard tool for monitoring quality of maternal health care. Best Pract Res Clin Obstet Gynaecol 2009;23(03):287-296

4 Assari S. Number of chronic medical conditions fully mediates the effects of race on mortality; 25-year follow-up of a nationally representative sample of Americans. J Racial Ethn Health Disparities 2016; [Epub ahead of print]

5 Knight M, Kurinczuk JJ, Spark P, Brocklehurst P; UKOSS. Inequalities in maternal health: national cohort study of ethnic variation in severe maternal morbidities. BMJ 2009;338:b542

6 Nair M, Kurinczuk JJ, Knight M. Ethnic variations in severe maternal morbidity in the UK- a case control study. PLoS One 2014;9(04):e95086

7 Martins AL. [Maternal mortality among black women in Brazil]. Cad Saude Publica 2006;22(11):2473-2479

8 Caughey AB, Stotland NE, Washington AE, Escobar GJ. Maternal ethnicity, paternal ethnicity, and parental ethnic discordance: 
predictors of preeclampsia. Obstet Gynecol 2005;106(01): 156-161

9 Tucker MJ, Berg CJ, Callaghan WM, Hsia J. The Black-White disparity in pregnancy-related mortality from 5 conditions: differences in prevalence and case-fatality rates. Am J Public Health 2007;97(02):247-251

10 Brasil. Ministério da Saúde. Centro Brasileiro de Análise e Planejamento [Internet]. [National Research on Demography and Health of Child and Woman: PNDS 2006]. Brasília (DF): 2009 [cited 2016 Jul 28]. Available from: http://bvsms.saude.gov.br/ bvs/publicacoes/pnds_crianca_mulher.pdf. Portuguese

11 Souza JP, Cecatti JG, Pacagnella RC, et al. Development and validation of a questionnaire to identify severe maternal morbidity in epidemiological surveys. Reprod Health 2010;7:16

12 Souza JP, Parpinelli MA, Amaral E, Cecatti JG. Population surveys using validated questionnaires provided useful information on the prevalence of maternal morbidities. J Clin Epidemiol 2008; 61(02):169-176

13 Souza JP, Cecatti JG, Faundes A, et al; World Health Organization 2005 Global Survey on Maternal and Perinatal Health Research Group. Maternal near miss and maternal death in the World Health Organization's 2005 global survey on maternal and perinatal health. Bull World Health Organ 2010;88(02):113-119

14 Dias MA, Domingues RM, Schilithz AO, et al. Incidence of maternal near miss in hospital childbirth and postpartum: data from the Birth in Brazil study. Cad Saude Publica 2014;30(Suppl 1):S1-S12
15 Instituto Brasileiro de Geografia e Estatística [Internet]. Distribuição espacial da população segundo cor ou raça - pretos e pardos. 2010 [citado 2015 Mar 27]. Disponível em: ftp://geoftp. ibge.gov.br/cartas_e_mapas/mapas_do_brasil/sociedade_e_economia/mapas_murais/brasil_pretos_pardos_2010.pdf

16 Domingues RM, Dias MA, Schilithz AO, Leal MD. Factors associated with maternal near miss in childbirth and the postpartum period: findings from the birth in Brazil National Survey, 2011-2012. Reprod Health 2016;13(Suppl 3):115

17 Zamora-Kapoor A, Nelson LA, Buchwald DS, Walker LR, Mueller BA. Pre-eclampsia in American Indians/Alaska natives and whites: the significance of body mass index. Matern Child Health J 2016;20(11):2233-2238

18 Zwart JJ, Jonkers MD, Richters A, et al. Ethnic disparity in severe acute maternal morbidity: a nationwide cohort study in the Netherlands. Eur J Public Health 2011;21(02):229-234

19 Howell EA, Egorova N, Balbierz A, Zeitlin J, Hebert PL. Black-white differences in severe maternal morbidity and site of care. Am J Obstet Gynecol 2016;214(01):122.e1-122.e7

20 Grobman WA, Bailit JL, Rice MM, et al; Eunice Kennedy Shriver National Institute of Child Health and Human Development (NICHD) Maternal-Fetal Medicine Units (MFMU) Network. Racial and ethnic disparities in maternal morbidity and obstetric care. Obstet Gynecol 2015;125(06):1460-1467

21 Louis JM, Menard MK, Gee RE. Racial and ethnic disparities in maternal morbidity and mortality. Obstet Gynecol 2015;125(03):690-694 